\title{
From Jerusalem to the Archives
}

Written history must be contrapuntal, not harmonic.

CHARLES MAIER

A black-and-white photograph that exists in duplicate in the archives of the Latin Patriarchate of Jerusalem shows a group of children seated at a table, looking toward the photographer, with pieces of bread in their hands, while a nun distributes more bread (fig. o.1). The caption reads "Group of children in a refugee camp". In fact, on closer inspection, the image turns out to be a snapshot of the preparations for a first communion ceremony, celebrated in Amman in 1951, which is also confirmed by the presence in the background of some little girls dressed in white with wreaths on their heads. As symbolized by the ambivalence of this picture, for the Latin Church of Jerusalem the decade that followed the 1947-49 Palestine War, and particularly the shattering events and harsh battles of 1948, was taken up with aiding refugees and the difficult

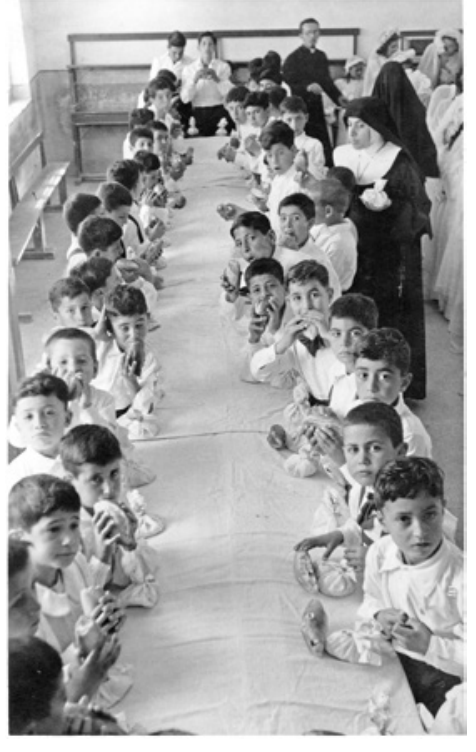

FIGURE 0.1

"Group of children in a refugee camp." In another album, captioned "First communion in 1951" in Amman APLJ/AEBAF 
task of resuming the ordinary daily life of a community of the faithful, punctuated by its liturgies and celebrations of the sacraments.

The community of the Latin-rite Roman Catholic patriarchal diocese of Jerusalem constitutes one of the most important components in the complex reality of the Catholic and, in a wider perspective, Christian world of the so-called "Holy Land". The Catholic Church in the Middle East is composed of seven churches, all of them under the authority of the pope: the Eastern Catholic churches - the Melkite, Maronite, Chaldean, Coptic, Syrian and Armenian - and the Roman Catholic Church, most of whose adherents are under the jurisdiction of the Latin Patriarchate of Jerusalem. The former preserve the various Eastern rites (hence their description as "Eastern Catholics") while the latter follows the Western Latin rite (and therefore its members are called "Latins"). Geographically, at the moment of its reestablishment in 1847, the borders of the Latin Patriarchate were delimited to the north by the Ras al-Abyad promontory up to the southern tip of Mount Hermon, to the east by the Syrian desert, to the south by the al-'Arish river, and to the west by the Mediterranean Sea, including the island of Cyprus. Nowadays, the Latin Catholic diocese extends through Israel, the Occupied Palestinian Territories, Jordan and Cyprus, comprising some 293,053 faithful.

On the eve of the 1947-49 Palestinian War, the Latin community was one of the largest Christian groups in Palestine and Transjordan. ${ }^{1}$ The diocesan territory comprised around 35,00o faithful, with 51 parishes, 138 religious houses, 32 schools for boys with more than 7,300 pupils, 65 schools for girls with more than 10,500 pupils, and 43 charitable institutions. Within this network of operations, then as now, there was the vast, centuries-old religious, educational and charitable presence of the Franciscan Custody of the Holy Land, established in 1217 and whose main task was and still is the safeguarding of the Holy Places.

1 According to the British Mandatory census in 1931, the largest Christian community in Palestine were the Greek Orthodox $(39,727)$, the Catholic Latin $(18,895$, the majority of whom were female) and Melkite $(12,645)$ communities. See Eric Mills, Census of Palestine 1931, vol. 1, pt. 1, Report (Alexandria: Government of Palestine, 1933), 99. Rough estimates for the Latin population in Palestine after the Second World War refer to around 25,000-30,000 faithful. According to patriarchal data, in 1947 Transjordan had a total population of around 400,00o inhabitants, who were mostly Muslim. The Christians in Transjordan numbered around 40,000, of whom 11,094 were Catholic (7,343 Latins and 3,751 Melkites). See Adolphe Perrin, Centenaire du Patriarcat latin de Jérusalem, 1847-1947 (Jerusalem: Patriarcat Latin, 1947), "Remarques," unpaginated. The most populous Latin parishes were those of Jerusalem, Bethlehem and Amman. 
The history of the Latin Patriarchate cannot be fully understood outside the broader picture of Christianity in the Middle East. Since the 1990s, historical studies in this field have experienced rapid growth. ${ }^{2}$ These new narratives rejected the description of Eastern Christians as "victims" and "symbols", as presented in contemporary Western media and political discourse. ${ }^{3}$ They also marked a revision of the historiographic paradigms that, in previous decades, had consigned the Christians to the parameters of the ahl al-dhimmi within the millet system of the Ottoman era, isolated from other majority communities, or subject to the service of Western powers. ${ }^{4}$ Thus, moving beyond these

2 For a bibliographical review of some of the principal studies on the Christians in the Middle East, see Cesare Santus, Trasgressioni necessarie: communicatio in sacris, coesistenza e conflitti tra le comunità cristiane orientali (Levante e Impero ottomano, XVII-XVIII secolo) (Rome: École française de Rome, 2019); Andreas Schmoller, ed., Middle Eastern Christians and Europe: Historical Legacies and Present Challenges (Münster: LIT, 2018); Bernard Heyberger, Les chrétiens d'Orient (Paris: PUF, 2017); Giorgio Fedalto, Le Chiese d'Oriente: Sintesi storica (Verona: Mazziana, 2016); Heyberger, Les chrétiens au Proche-Orient: De la compassion à la compréhension (Paris: Payot \& Rivages, 2013); Anthony O'Mahony, and John Flannery, eds., The Catholic Church in the Contemporary Middle East: Studies for the Synod for the Middle East (London: Melisende, 2010); O'Mahony, ed., Eastern Christianity: Studies in Modern History, Religion and Politics (London: Melisende, 2004); Heyberger, ed., Chrétiens du monde arabe: Un archipel en terre d'Islam (Paris: Autrement, 2003); Andrea Pacini, ed., Christian Communities in the Arab Middle East: The Challenge of the Future, trans. Fiona Tupper-Carey (New York: Clarendon, 1998); Ronald G. Roberson, The Eastern Christian Churches: A Brief Survey (Rome: Orientalia Christiana, 1995); Heyberger, Les chrétiens du Proche-Orient au temps de la Réforme catholique (Syrie, Liban, Palestine, XVII ${ }^{e}-X V I I I^{e}$ siècle) (Rome: École française de Rome, 1994). For an analysis of the relationship between Christians, Jews, and Muslims, see Heather J. Sharkey, A History of Muslims, Christians, and Jews in the Middle East (Cambridge: Cambridge University Press, 2017); Heleen L. Murre-van den Berg and Sasha Goldstein-Sabbah, eds., Searching for Common Ground: Jews and Christians in the Modern Middle East (Leiden: Brill, 2016); and Bruce Masters, Christians and Jews in the Ottoman Arab World: The Roots of Sectarianism (Cambridge: Cambridge University Press, 2001).

3 See Paul Sedra, "Writing the History of the Modern Copts: From Victims and Symbols to Actors," History Compass 7, no. 3 (2009). As Bernard Heyberger summarizes it poignantly: "News abounds regarding violence and injustices committed against Christians in various countries and about their ever-shrinking numbers due to emigration. However, this approach, which depicts Eastern Christians only as victims, prevents us from understanding their actual situation in the home countries or in the diaspora." "Eastern Christians, Islam, and the West: A Connected History," IJMES 42, no. 3 (2010): 475.

4 See the controversial thesis of Bat Ye'or in The Dhimmi: Jews and Christians Under Islam, trans. David Maisel, Paul Fenton, and David Littman (London: Associated University Press, 1985) and The Decline of Eastern Christianity under Islam: From Jihad to Dhimmitude, trans. Miriam Kochan and David Littman (Madison, NJ: Fairleigh Dickinson University Press, 1996). 
sectarian categories and, instead, recognizing the Christians as agents (and no longer as victims of political persecution or as collaborators with foreign powers), a connected history of the Christian communities of the Middle East has emerged, and is being continuously enriched by new contributions. ${ }^{5}$ As regards the late Ottoman era, the Christian contribution to the nahda, the cultural renaissance in the second half of the nineteenth century, and to the formation of Arab nationalism is becoming ever clearer. ${ }^{6}$

There has also been a renewal in the study of the Palestinian and Jordanian Christians, particularly in research on the late Ottoman and Mandate periods, which has unpacked the contribution of the Christians in the construction of a new political, economic and cultural middle class, and their participation in the creation of the emerging Arab identities and, at the same time, in cultivating global links. ${ }^{7}$ This historiographical rejuvenation is a consequence of

5 Besides the already quoted pioneering works of Bernard Heyberger, see Akram Khater, Embracing the Divine: Passion, Politics and Gender in the Christian Middle East, 1720-1798 (Syracuse, NY: Syracuse University Press, 2011); Paul Rowe, "Building Coptic Civil Society: Christian Groups and the State in Mubarak's Egypt," Middle Eastern Studies 45, no. 1 (2009); Fiona McCallum, "The Political Role of the Patriarch in the Contemporary Middle East," Middle Eastern Studies 43, no. 6 (2007); Peter Makari, Conflict and Cooperation: Christian-Muslim Relations in Contemporary Egypt (Syracuse, NY: Syracuse University Press, 2007), and Sana S. Hasan, Christians versus Muslims in Modern Egypt: The Century-Long Struggle for Coptic Equality (Oxford: Oxford University Press, 2003).

6 See Salim Tamari, The Great War and the Remaking of Palestine (Oakland: University of California Press, 2017), 89-9o.

7 See Stéphane Ancel, Magdalena Krzyżanowska, and Vincent Lemire, Le moine sur le toit: Histoire d'un manuscrit trouvé à Jérusalem (1904) (Paris: Publications de la Sorbonne, 2020); Yusri Khaizran, "Difference, not Fragmentation:Christians and Druze in Mandatory Palestine," in The British Mandate in Palestine: A Centenary Volume, 1920-2020, ed. Michael J. Cohen (Abingdon: Routledge, 2020); and numerous chapters in Angelos Dalachanis and Vincent Lemire, eds., Ordinary Jerusalem, 1840-1940: Opening New Archives, Revisiting a Global City (Leiden: Brill, 2018), in particular Stéphane Ancel, "The Ethiopian Orthodox Community in Jerusalem: New Archives and Perspectives on Daily Life and Social Networks, 1840-1940"; Lora Gerd and Yann Potin, "Foreign Affairs through Private Papers: Bishop Porfirii Uspenskii and His Jerusalem Archives, 1842-186o"; Angelos Dalachanis and Agamemnon Tselikas, "The Brotherhood, the City and the Land: Patriarchal Archives and Scales of Analysis of Greek Orthodox Jerusalem in the Late Ottoman and Mandate Periods," and Konstantinos Papastathis, "Diplomacy, Communal Politics, and Religious Property Management: The Case of the Greek Orthodox Patriarchate of Jerusalem in the Early Mandate Period". See also the important contributions by Karène Sanchez Summerer, "Linguistic Diversity and Ideologies among the Catholic Minority in Mandate Palestine: Fear of Confusion or Powerful Tool?" British Journal of Middle Eastern Studies 43, no. 2 (2016); Noah Haiduc-Dale, Arab Christians in British Mandate Palestine: Communalism and Nationalism, 1917-1948 (Edinburgh: Edinburgh University Press, 2013); Laura Robson, Colonialism and Christianity in Mandate Palestine (Austin, TX: University of Texas Press, 2011); Paolo Maggiolini, Arabi 
and has incentivized the ordering of numerous archives belonging to several Christian communities in Jerusalem, albeit with greatly varying degrees of rigor in the cataloging process, the extent of the inventorying and the accessibility to scholars. Countless topics for research remain open. The historiography of the Christians in the Palestine War is still limited, is not sufficiently grounded on archival sources and is frequently based on ideological convictions that portray the various Christian communities as monolithically aligned with anti-Israeli and anti-Muslim positions, although they are internally divided on confessional issues and on the management of the Holy Places. A closer look reveals the limits of these interpretations and a much more complex reality. After the end of the Second World War, the Latin Church of Jerusalem faced burning and dramatic questions: the beginning of the debate on the role of Pius XII and Catholic representatives and organizations during the Shoah; the burden of decades of tension and suspicion between the Holy See and the Zionist movement; as well as the Latin Patriarchate hierarchy's uncertain stance on Arab nationalist demands and on the transformations resulting from the announcement of the end of the British Mandate over Palestine and Transjordan.

My contribution aims to analyze the variety of actions that matured within the Latin Church of Jerusalem in the decade marked by the resumption of the discussion concerning the partition of Palestine in 1945, the Palestine War, the establishment of the Israeli state in 1948, the Jordanian annexation of the West Bank in 1950 and the consolidation of the Hashemite Kingdom, up to the Suez crisis in 1956. In this changing scenario, the Latin Patriarchate of Jerusalem engaged in multiple and sometimes contrasting pastoral initiatives, humanitarian missions, theological reflections, political relations and liturgical responses.

As it is well known, the reconstruction of the events and interpretation of the circumstances that led to, concerned and followed the "long 1948 " has been approached by different and opposite historiographies and narratives.

Cristiani di Transgiordania: Spazi politici e cultura tribale (1841-1922) (Milan: FrancoAngeli, 2011); Géraldine Chatelard, Briser la mosaïque: Les tribus chrétiennes de Madaba, Jordanie, $X I X^{e}-X X^{e}$ siècle (Paris: CNRs, 2004); Anthony O'Mahony, ed., The Christian Communities of Jerusalem and the Holy Land: Studies in History, Religion and Politics (Cardiff: University of Wales Press, 2003), and O'Mahony, ed., Palestinian Christians: Religion, Politics and Society in the Holy Land (London: Melisende, 1999). On the relations between Christians, Muslims and Jews in Palestine from the end of the nineteenth century to the First World War, see Erik Freas, Muslim-Christian Relations in Late Ottoman Palestine: Where Nationalism and Religion Intersect (London: Palgrave Macmillan, 2016), and the seminal book by Michelle U. Campos, Ottoman Brothers: Muslims, Christians, and Jews in Early Twentieth-Century Palestine (Stanford, CA: Stanford University Press, 2011). 
Since the 1950s, Arab authors have published numerous appraisals that aim to highlight Israeli responsibility for the Palestinian disaster and refugee problem. ${ }^{8}$ These accounts, often marked by nationalist and apologetic intentions, are lacking in historical accuracy. In parallel, Israeli historiography in its first decades was an expression of Zionist nationalist aims. Since the 1980s, there have been changes in and divergences from the historical narrative of the events of 1948, brought about in particular through the use of sources contained in the Israeli archives that were hitherto inaccessible. Numerous works, especially those of the "new Israeli historians" reviewed and dismantled the "founding myths" elaborated by Jewish Israeli nationalist scholars on the 1948 war, ${ }^{9}$ although with aporias and opaque aspects..$^{10}$ New fresh research by Palestinian and non-Middle Eastern scholars has contributed to the historicization of the political, humanitarian and identity watershed of $1948 .{ }^{11}$

8 Some Arab authors published seminal works in Arabic, such as Constantine Zurayk, Ma'nat al-Nakba [The meaning of the catastrophe] (Beirut: Khayat, 1948); 'Arif al-'Arif, al-Nakba: Nakbat Bayt al-Maqdis wa al-Firdaws al-Mafqud, 1947-1952 [The catastrophe: the catastrophe of Jerusalem and the lost paradise, 1947-52], 6 vols. (Beirut and Sidon: Al-Maktaba al-'Asriyya, 1958-6o); Falih Khalid 'Ali, al-Harb al-Arabiyya al-Isra'iliyya, 19481949, wa Ta'sis Isra'il [The Arab-Israeli War, 1948-1949, and the establishment of Israel] (Beirut: al-Mu'asasa al-'Arabiyya lil-Dirasat wal-Nashr, 1982).

$9 \quad$ Examples of this revisionism are Tom Segev, 1949: The First Israelis, trans. Arlen Neal Weinstein, new ed. (New York: Free Press, 2018); Avi Shlaim, The Iron Wall: Israel and the Arab World, 2nd ed. (New York: Norton, 2014); Benny Morris, 1948: A History of the First Arab-Israeli War (New Haven, CT: Yale University Press: 2008); Ilan Pappé, The Ethnic Cleansing of Palestine (Oxford: Oneworld, 2006); Morris, The Birth of the Palestinian Refugee Problem Revisited, 2nd ed. (Cambridge: Cambridge University Press, 2004); Zeev Sternhell, The Founding Myths of Israel: Nationalism, Socialism, and the Making of the Jewish State, trans. David Maisel (Princeton: Princeton University Press, 1997); Ilan Pappé, The Making of the Arab-Israeli Conflict, 1947-51 (London: I.B. Tauris, 1992); Shlaim, Collusion Across the Jordan: King Abdullah, the Zionist Movement and the Partition of Palestine (Oxford: Clarendon, 1988), and Simha Flapan, The Birth of Israel: Myths and Realities (New York: Pantheon, 1987). For a contextualization of the new Israeli historiography and sociology, see the collection of essays edited by the main and most controversial - given his radical change in thinking after the outbreak of the al-Aqsa Intifada in 2000 - Israeli historian Benny Morris, Making Israel (Ann Arbor: University of Michigan Press, 2007). The potentials of the post-1980s Israeli historiography are clarified in the introduction of Eugene L. Rogan and Avi Shlaim, eds., The War for Palestine: Rewriting the History of 1948, 2nd ed. (Cambridge: Cambridge University Press, 2007). A 1989 but still valid Palestinian appraisal of these studies by Israeli scholars is Ibrahim Abu-Lughod, "The War of 1948: Disputed Perspectives and Outcomes," Journal of Palestine Studies 18, no. 2 (1989).

11 See the works by Rashid Khalidi, The Hundred Years' War on Palestine: A History of Settler Colonialism and Resistance, 1917-2017 (New York: Metropolitan, 2020); James L. Gelvin, The Israel-Palestine Conflict: One Hundred Years of War, 3rd ed. (Cambridge: Cambridge 
Concerning the role of Christians, and Catholics in particular, historiography generally concentrated on the relations between the Holy See and Israel. The dialectic between the new state, the Kingdom of Jordan and the local Catholic Church remains largely unexplored, particularly with respect to its principal institutions, the Latin Patriarchate ${ }^{12}$ and the Franciscan Custody. ${ }^{13}$ An analysis of different documentary typologies from dozens of archives around the world allows for a reconstruction of the church's complex relations with Israel and Jordan and with the social, religious, and material changes resulting from the epochal 1947-49 war. These records reconstruct a composite narrative of the Latin Church, showing how it related to Israel and Jordan and to the social, religious, and material changes occasioned by the epochal war through the redetermination of the categories that, up to that point, had defined the traditional Catholic hostility toward Zionism and the ambiguous and fluctuating support for the Arab Palestinian cause, largely motivated by fear of Muslim reprisals against Christians.

Some historians have presented the Latin Church as the most hostile Christian component to the State of Israel. ${ }^{14}$ However, a more careful historical

University Press, 2013); Thomas Grant Fraser, The Arab-Israeli Conflict, 3rd ed. (New York: Palgrave Macmillan, 2007); Salim Tamari, ed., Jerusalem 1948: The Arab Neighbourhoods and Their Fate in the War, 2nd rev. ed. (Jerusalem: Institute of Jerusalem Studies; Bethlehem: Badil, 2002); Charles D. Smith, Palestine and the Arab-Israeli Conflict: A History with Documents (Boston: Bedford; St. Martin's, 2001); Henry Laurens, Le retour des exilés: La lutte pour la Palestine de 1869 à 1997 (Paris: Robert Laffont, 1998); Walid Khalidi, All That Remains: The Palestinian Villages Occupied and Depopulated by Israel in 1948 (Washington, DC: Institute for Palestine Studies, 1992); and Elias Sanbar, Palestine 1948: L'expulsion (Paris: Les Livres de la Revue d'études palestiniennes, 1985).

12 On the institutional history of the Latin Patriarchate, see in particular the studies by Paolo Pieraccini, Il ristabilimento del Patriarcato latino di Gerusalemme e la Custodia di Terra Santa: La dialettica istituzionale al tempo del primo patriarca Mons. Giuseppe Valerga (1847-1872) (Cairo: Franciscan Centre of Christian Oriental Studies; Jerusalem: Franciscan Printing Press, 2006); Pieraccini, "Il ristabilimento del patriarcato latino di Gerusalemme (1842-1851)," Cristianesimo nella storia 27, no. 3 (2006).

13 On the Custody of the Holy Land in the contemporary period, see Giuseppe Buffon, Les Franciscains en Terre Sainte (1869-1889): Religion et politique; une recherche institutionnelle (Paris: Cerf; Editions franciscaines, 2005); Paolo Pieraccini, Cattolici di Terra Santa (1333-2000) (Florence: Pagnini e Martinelli, 2003); Andrea Giovannelli, La Santa Sede e la Palestina. La Custodia di Terra Santa tra la fine dell'impero ottomano e la guerra dei sei giorni (Rome: Studium, 200o).

14 On this thesis, supported by Uri Bialer and Daphne Tsimhoni, see especially Tsimhoni's arguments in The Christian Communities in Jerusalem and the West Bank Since 1948: An Historical, Social and Political Study (Westport, CT: Praeger, 1993), 10. Tsimhoni is the most prolific Israeli scholar on Palestinian Christians. See her "ha-Notsrim be-Yisra'el: Bein 
examination cannot limit itself to such a reductive interpretation of the complex relations between the Latin Church and Israel. Indeed, in a context of tense and delicate connections, there were elements of innovation and partial disruption; an example is the group of priests and laymen organized in the Association of Saint James, a reflection within the patriarchate of the necessity for a new era in the relations between Jews and Catholics, in light of the foundation of the Israeli state. The study of these contrasting tensions, contained within the same ecclesiastical horizon, enables a better comprehension of the successive transformations in the relations between the Catholic Church and Jews, but also with the Muslim world, around the Second Vatican Council (1962-65) and its reception in following decades.

Diocesan History: Renewing the Paradigms

The examination of this period also makes it possible to shed new light on the history of a city, Jerusalem, which, in the modern and contemporary period, has often been circumscribed and reduced to the status of a battleground or site of the Holy Places. The need for a different perspective on the urban space of Jerusalem is reflected in the importance of taking account of the Christians, men and women, laity and clergy - both diocesan and religious - who lived in the city. ${ }^{15}$ Equally, the history of the various religious communities has

Dat le-Politika" [The Christians in Israel: between religion and politics], in ha-Aravim baPolitika ha-Yisra'elit:Dilemot shel Zehut [The Arabs in Israeli policy: dilemmas of identity], ed. Elie Rekhess (Tel Aviv: Moshe Dayan Center, Tel Aviv University, 1998); "ha-Ma'arah ha-Politi shel ha-Notsrim" [The political configuration of the Christians], in "ha-'Aravim be-Yisra'el: Bein Tehiyah Datit le-Hit'orerut Le'umit [Arabs in Israel: between religious revival and national awakening], special issue, ha-Mizrah ha-Hadash 32 (1989); "The Status of the Arab Christians under the British Mandate in Palestine," Middle Eastern Studies 20, no. 4 (1984); "The Armenians and the Syrians: Ethno-Religious Communities in Jerusalem," Middle Eastern Studies 20, no. 3 (1984), and "Demographic Trends of the Christian Population in Jerusalem and the West Bank 1948-1978," Middle East Journal 37, no. 1 (1983).

15 For important suggestions on and new methodological approaches to the study of the history of Jerusalem and Palestine in the late Ottoman and British periods, see Rashid Khalidi and Salim Tamari, The Other Jerusalem: Rethinking the History of the Sacred City (Washington, DC: Institute for Palestine Studies; Jerusalem: Khalidi Library, 2020); Vincent Lemire, Jerusalem 19oo: The Holy City in the Age of Possibilities, trans. Catherine Tihayni and Lys Ann Weiss (Chicago: University of Chicago Press, 2017); Lorenzo Kamel, Imperial Perceptions of Palestine: British Influence and Power in Late Ottoman Times (London: I.B. Tauris, 2015); Jonathan Marc Gribetz, Defining Neighbors: Religion, Race, and the Early Zionist-Arab Encounter (Princeton: Princeton University 
frequently been compartmentalized and consigned to rigid, noncommunicative categories, following the ethnic construction of Middle Eastern identities elaborated in the long nineteenth century by European and American diplomats and intellectuals. ${ }^{16}$ The significance of considering the Catholic component within a broader context and accounting for its own multiformity opens the way to a revision of the interpretative paradigms that have thus far described the forms of contemporary Christianity in Palestine, Israel and Jordan during and after the Palestine War. ${ }^{17}$

Exploring the history of the Latin patriarchal diocese means researching the Christians, particularly the Latin Catholics, tracing their itineraries within the parishes and as refugees, and, at the same time, reconstructing the evolution of the relationship between the Catholic hierarchies in Jerusalem and in Rome, but also in other Middle Eastern and European countries, in the United States and in Latin America. Thus, it demands a study that distinguishes itself from the approach to the history of international relations frequently adopted in other works. The methodological approach chosen in this work stands out within religious history, and particularly the history of Christianity, privileging the particular heuristic path that is the history of the diocese. ${ }^{18}$

Press, 2014); Jacob Norris, Land of Progress: Palestine in the Age of Colonial Development, 1905-1948 (Oxford: Oxford University Press, 2013); Johann Büssow, Hamidian Palestine: Politics and Society in the District of Jerusalem, 1872-1908 (Leiden: Brill, 2011); Abigail Jacobson, From Empire to Empire: Jerusalem between Ottoman and British Rule (Syracuse, NY: Syracuse University Press, 2011); Lemire, La soif de Jérusalem: Essai d'hydrohistoire (1840-1948) (Paris: Publications de la Sorbonne, 2010); Roberto Mazza, Jerusalem: From the Ottomans to the British (London: I.B. Tauris, 2009); Catherine Nicault, Une histoire de Jérusalem (1850-1967) (Paris: CNRs, 2008); Gudrun Krämer, A History of Palestine: From the Ottoman Conquest to the Founding of the State of Israel, trans. Graham Harman and Gudrun Krämer (Princeton: Princeton University Press, 2008); and Beshara Doumani, Rediscovering Palestine: Merchants and Peasants in Jabal Nablus, 1700-1900 (Berkeley: University of California Press, 1995).

16 For an innovative and archival-based appraisal of the nineteenth- and early twentiethcentury process of the Western creation of the modern Middle East and the "racialization" of the Middle Eastern people, see Lorenzo Kamel, The Middle East from Empire to Sealed Identities (Edinburgh: Edinburgh University Press, 2019).

17 Although the research mainly focuses on these areas, the history of the Cyprus Catholic community and its specific features deserve further study. A seminal contribution is Paolo Pieraccini, The Franciscan Custody of the Holy Land in Cyprus (1191-1960): Its Educational, Pastoral and Charitable Work and Support for the Maronite Community (Milan: Terra Santa, 2013).

18 See Christian Sorrel, "Échelles et espaces: le diocèse. Réflexions sur l'historiographie française contemporaine," in L'histoire religieuse en France et en Espagne, ed. Benoît Pellistrandi (Madrid: Casa de Velázquez, 2004); Gérald Chaix, ed., Le diocèse: Espaces, représentations, pouvoirs (France, $X V^{e}-X X^{e}$ siècle) (Paris: Cerf, 2002), and Michel Lagrée, 
The latter constitutes a branch of the history of Christianity that has undergone progressive marginalization in recent decades. Widely practiced in the medieval and modern ages (as shown by the diocesan chronicles that recorded events and activities within the diocese and its parishes), it has undergone various transformations since the nineteenth century, as the professionalization of the historical discipline redefined the tools and methods of historiographical research.

In the post-French Revolutionary Europe marked by the secularization process, the application of the historical-critical method to the history of the Catholic Church required a long and tortuous journey. The Catholic Church feared that resorting to the methodologies of modern historical science would amount to a revocation of the transcendent component in the history of Christianity. Therefore, it continued to reject the historical-critical method during the nineteenth century. The suspicion on the part of the Vatican hierarchy toward the modern historical-critical method reached its acme during the modernist crisis at the turn of the twentieth century. Historians of a Catholic orientation struggled to free themselves from the authority and control of the Holy See. However, since the Second Vatican Council, the definition of the epistemological status of the history of Christianity and particularly of the Catholic Church has moved structurally in the direction of autonomy from ecclesiastical control, in a constant effort to avoid a confessional characterization of their investigative discipline, and with some overt problems and contradictions. ${ }^{19}$ The distancing from the apologetic intention and from the subjection to theology - through a process that developed despite the resistance, opposition and also wavering on the part of the protagonists themselves - has thus permitted the development of a modern history of Christianity that is no longer limited to the study of Catholicism and is able to offer an in-depth diachronic and synchronic analysis.

In the middle of the twentieth century, too, the diocesan monography produced in the academic context began to be based on a more rigorous and

"La monographie diocésaine et les acquis de l'historiographie religieuse française," Études d'histoire religieuse 61 (1995).

19 See Jean-Dominique Durand, "Le parcours de l'histoire religieuse dans l'évolution culturelle européenne," Lusitania Sacra, 2nd ser., 21 (2009); Luc Courtois, Jean-Pierre Delville, Eddy Louchez, Jean Pirotte, Françoise Rosart and Guy Zélis, eds., Écrire l'histoire du catholicisme des XIX et XX ${ }^{e}$ siècles: Bilan, tendances récentes et perspectives (1975-2004); Hommage au prof. Roger Aubert à l'occasion de ses go ans (Louvain-la-Neuve: ARCA, 2005); Jean-Dominique Durand and Régis Ladous, eds., Histoire religieuse. Histoire globale - histoire ouverte: Mélanges offerts à Jacques Gadille (Paris: Beauchesne, 1992), and Giuseppe Alberigo, "Méthodologie de l'histoire de l'Église en Europe," Revue d'histoire ecclésiastique 81, nos. 3-4 (1986). 
attentive methodology, thus inaugurating a new religious historiography. The areas of focus slowly departed from the tradition of the medieval and modern diocesan monograph, formerly confined to the biography of illustrious bishops, to embrace modern historical research. In France - and subsequently beyond its borders - the contribution offered by the revolution sparked by the Annales school can also be discerned in this field, too; thanks to the works of Lucien Febvre, Marc Bloch and Fernand Braudel, among others, economic and social history, as well as the history of mentalities and geography, have rightfully joined the methodologies that guide the act of making the history of the diocese, paving the way to long-term periodization. ${ }^{20}$

The principal topic in this context continued to be the history of French dioceses, monumental works composed of over twenty volumes, the first of which was published in $1967 .{ }^{21}$ This Histoire represented the first relevant attempt to apply religious sociology with a historical bent to modern religious history, making an effort to surmount erudition and confessionalism, in a process that is still underway.

Although it may be true that numerous "histories of dioceses" exist in the European context, the research in religious history seems to have progressively abandoned this object of study since the 196os and 1970s and to have confined itself mainly to the area of local history. This does not mean that there is a lack of works of great interest and value as regards the history of the clergy and of Catholic institutions. However, the growth in diocesan history has not kept pace with the general growth of religious historiography. Still too few diocesan monographs have taken advantage of the methodological developments proposed by recent contributions in the blossoming of cultural and religious studies, ${ }^{22}$ including the study of the liturgy, religious practices and Catholic movements, with some important exceptions, especially concerning research on dioceses during the First World War. ${ }^{23}$ From the geographical point of view, moreover, most research is focused on European or North American case

20 One of the first histories of dioceses that relies on the impulses produced by Annales historians was the volume by Christiane Marcilhacy, Le diocèse d'Orléans sous l'épiscopat de Mgr Dupanloup, 1849-1878: Sociologie religieuse et mentalités collectives (Paris: Plon, 1962).

21 The Histoire des diocèses de France, founded by Eugène Jarry and Jean-Remy Palanque, published four volumes in the first series and twenty-two in the second, is now edited by Bernard Plongeron and André Vauchez.

22 See Massimo Faggioli and Alberto Melloni, ed., Religious Studies in the 2oth Century: A Survey on Disciplines, Cultures and Questions (Münster: LIT, 2006).

23 This is the case of Matteo Caponi, Una Chiesa in guerra: Sacrificio e mobilitazione nella diocesi di Firenze, 1911-1928 (Rome: Viella, 2018), and Xavier Boniface and Jean Heuclin, eds., Diocèses en guerre, 1914-1918: L'Église déchirée entre Gott mit uns et le Dieu des armées (Villeneuve-d'Ascq: Presses universitaires du Septentrion, 2018). 
studies, while studies that apply the methodology of the history of the diocese to other continents and cultural and religious traditions are very rare. ${ }^{24}$ The Catholic world of Asia, Africa and Latin America has remained the object of the history of missions, through the reconstruction of the penetration of religious congregations in the colonial and postcolonial eras, neglecting the evolution of the dioceses in these contexts.

The first issue requiring action is the definition of terms, first and foremost that of diocese. From the point of view of Roman Catholic canon law, the diocese is a portion of the faithful, territorially limited, under the control and administration of a bishop. ${ }^{25}$ It is divided into vicariates and parishes, which represent its principal units. To study a diocese is to move on uneven terrain, to concentrate on different actors, analyze the personalities who comprise its governance (mainly the bishop, vicars and episcopal curia) and the forms of synodality, but also the behavior and ideas of the clergy and of the male and female faithful, as well as the religious institutions that contribute to the life of the diocese in its complexity. The forms of worship, piety, devotion, customs and pilgrimages constitute other elements that define and shape Christian life at the diocesan level and elsewhere. A historical work that asks questions about the life of a diocese in a precise period cannot do so without the investigation of the territory in which the diocese exists and of its historical, economic and demographic characteristics.

A further element that must not be neglected concerns the relations between the local church and the central authority. The relationship with the Vatican, expressed not only in the direct relations between the bishop and the organs of the Roman curia, but also by impulses in terms of initiatives and forms of worship proposed by the center and received and elaborated on further out, constitutes an interesting subject for examination. In the same way, the relations with political institutions and the other religious denominations active within the diocesan territory, in particular in contexts in which the Catholic presence constituted a minority, represents a significant element.

24 See Terry Golway, ed., Catholics in New York: Society, Culture and Politics, 1808-1946 (New York: Fordham University Press; Museum of the City of New York, 2008); Thomas J. Shelley, The Bicentennial History of the Archdiocese of New York, 1808-2008 (Strasbourg: Signe, 2007); Christine Hudon, Prêtres et fidèles dans le diocèse de Saint-Hyacinthe, 1820-1875 (Sillery: Septentrion, 1996), and Pierre Guillaume, ed., Le diocèse au Québec et en France aux XIX $X^{e}$ et XX $X^{e}$ siècles (Bordeaux: Centre d'études canadiennes; Maison des sciences de l'homme d'Aquitaine, 1990).

25 The nature and structure of the diocese are established in cann. $368-572$ of the Codex of canon law. 
The 1940s and 195os, and especially the period from the 1947-49 war to the 1956 Suez crisis, represent a chronologically restricted but crucial phase that poses complex questions relating to the role of a diocese during an armed conflict and to the aid effort for thousands of refugees caused by the fighting and in relation to the new state forms ratified by the armistices. Above all, this period brought the church in close contact with the Jewish Israeli and the majority-Muslim Palestinian and Jordanian Arab societies. Through this confrontation born of tensions and contradictions, the very face of Catholicism in the region was transformed.

From a methodological perspective, the study of the Latin Church of Jerusalem also involves an attempt to depart from Eurocentric and Orientalist approaches which, albeit in very different ways compared to the past, still permeate some areas of church history. The case of the Latin patriarchal diocese of Jerusalem is particularly useful in this regard. This, indeed, is a local Latin-rite church, directly subordinate to the Holy See, but, at the same time, $a$ global diocese, composed of Arab and foreign clergy from all around the world and mostly attended by Arab faithful and a small group of Catholics of Jewish origin. This cultural multiformity mandates a polyphonic historical reconstruction that takes account of the differences - and, in the political context, of the divisions - without, however, overlooking the general tendencies that characterizes Christian life in Israel, Palestine and Jordan. The apparent homogeneity of an object of study such as a diocese reveals, in fact, a plurality of realities, situations and visions. And these differences are expressed through the various sources with which the history - the histories - of the Jerusalem diocese can be reconstructed and narrated.

\subsection{Newly Released Archives, Histories to Unpack}

Essential to this research has been work conducted within some ecclesiastical archives in Jerusalem. Working with ecclesiastical institutions requires the establishment of a relationship of trust, to break the suspicious attitude toward scholars, to go beyond the "negligence and secrecy" that often surround the archival practices in the Middle East. ${ }^{26}$ Archives are not inert loci of storage. They act as knowledge producers and not only as source containers. ${ }^{27}$

26 Karène Sanchez Summerer, "Entre négligence et secret: Entreprises archivistiques en Palestine," in Archiver au Moyen-Orient: fabriques documentaires contemporaines, ed. Christine Jungen and Jihane Sfeir (Paris: Karthala, 2019).

27 On the passage from archive-as-source to archive-as-subject, see Ann Laura Stoler, "Colonial Archives and the Arts of Governance," Archival Science 2, nos. 1-2 (2002). 


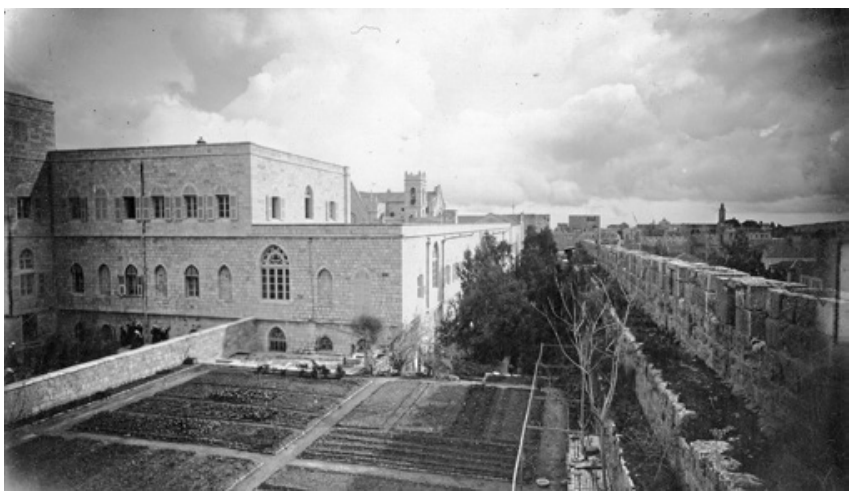

FIGURE 0.2 Seat of the Latin Patriarchate, Jerusalem APLJ/AEBAF

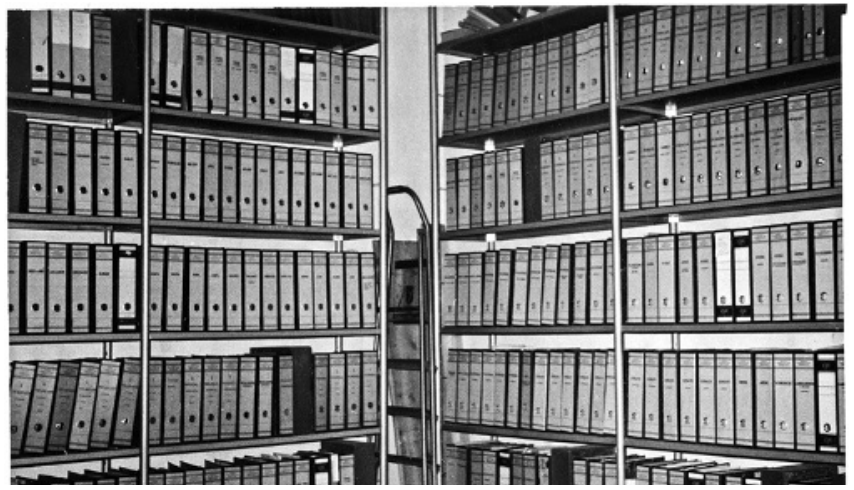

FIGURE 0.3 Archives of the Latin Patriarchate, 1962 APLJ/AEBAF

Archives have their own history, a history that in Jerusalem has often encountered conflicts and dispossessions, dispersal and incertitude.

For the history of people gravitating in the Jerusalem Latin diocese and the events of the mid-twentieth century, some archives are particularly crucial. The archives of the Latin Patriarchate are located in the patriarchal seat, near Jaffa Gate, in the so-called Christian Quarter of the Old City (figs. o.2o.3). At the initiative of the Latin hierarchy, these archives were reorganized and catalogued - although a detailed inventory does not exist - in a process that was completed at the beginning of this century under the patriarchate of Michel Sabbah (1987-2008), a Palestinian Israeli and the first non-Italian patriarch. The irregularity with which access is granted to researchers means that it is not possible to appraise with precision the consistency of the documentation gathered since 1847 . It is certainly a valuable archive, albeit heavily 
lacunose: it contains baptismal and marriage registers, parochial archives, correspondence with the patriarchal organs and the Roman curia, as well as with the local and imperial authorities and foreign consulates, relations with other religious congregations and with the other churches of Jerusalem, and the private papers of priests. The exploration of these sources, composed from the lives of men and women who constituted the Latin community, could contribute to the historical appraisal. The sources from this archive relating to the 1940 and 1950s consulted for this research are almost entirely unpublished.

The Franciscan Custody of the Holy Land, the other principal Catholic institution in Jerusalem, is a different story; the enormous documentary heritage from over 800 years of Franciscan presence in the region is contained in the archives of the Monastery of Saint Saviour, near the New Gate within the Old City, not far from the patriarchal archives. The immense work of reorganization and evaluation of the custodial archives culminated in the publication of a monumental, three-volume inventory totaling over 1,6oo pages. ${ }^{28}$

Other essential archives for researching the Catholics in the Holy Land are the archives of the Missionaries of Africa (White Fathers) at Saint Anne's; the archives of the Assumptionists, formerly in the Notre-Dame de France complex and now at Saint Peter's in Gallicantu; the archive of the Fathers of Sion deposited at Ratisbonne Monastery, and those of the Sisters of Sion contained at 'Ayn Karim Convent. The archives of associations also represent fundamental heritage. This is the case for the Association of Saint James, now the Hebrew-speaking Catholic Vicariate (Netsigut Ya'akov ha-Tsadik la-Katolim haDovrim (Ivrit be-Yisra'el) within the patriarchate, collected by Yohanan Elihai and now transferred to the seat of the kehilah - the vicariate community - on Rabbi Kook Street.

Diocesan archives relating to Jerusalem are also to be found outside that city. This history is disseminated among the Middle East, Europe, the United States, Canada, Latin America, Africa and Australia. The archives of the Catholic Near East Welfare Association (CNEWA), which in 2018 were transferred to the archives of the Archdiocese of New York, constitute a most precious source for the reconstruction of the global history of the Palestinian refugees and of the humanitarian aid network developed by the Catholic Church. The British, French, Italian, Israeli and US diplomatic archives show the connections between global history and the history of a diocese, that of a global city like

28 Andrea Maiarelli, ed., L'Archivio storico della Custodia di Terra Santa, 1230-1970, 3 vols. (Milan: Terra Santa, 2012). 
Jerusalem, and demonstrate the persistence of colonial attitudes and visions also after the end of the British Mandate for Palestine. ${ }^{29}$

The opening of the archives on the pontificate of Pius XII (1939-58) on March 2, 2020, a year after a related announcement by Pope Francis, has inaugurated unprecedented possibilities of enquiry for scholars working on the Christians in the Middle East. The full scope of what the archives reveal not only about Pius's wartime role - will only emerge after years of study by historians. ${ }^{30}$ This documentation will open up new questions, reframe hypotheses and challenge former interpretations.

Concerning the Jerusalem Roman Catholic diocese during the Palestine War and its aftermath, three archives are particularly relevant for this study: those of the Vatican Apostolic Archive, of the section for state relations of the Secretariat of State in Vatican City and of the Congregation for the Oriental Churches in Rome. Firstly, the archives of the Apostolic Delegation in Jerusalem and Palestine, preserved in the Vatican Apostolic Archive, shed light on the activities of the pontifical representative in the region during the Second World War, its connections with the Vatican and other delegations concerning the Holy See's initiatives during the Nazi extermination of the Jews. Moreover, these archives furnish the historian with new information regarding the church's actions and reactions in the new scenario determined by the 1948 war. Secondly, the archives of the Vatican Secretariat of State, which were in the process of being released at the time of writing, especially for the period from 1949 to 1958 , represent a fundamental documentary depository concerning not only the Holy See's diplomatic actions and the question of Jewish emigration to Palestine to escape Nazi extermination, but also the Vatican's role during the debate on the partition of Palestine and the status of Jerusalem, as well as the attitude of the church toward Israel and Jordan during the Cold War. Thirdly, the archives of the Congregation for the Oriental Churches reveal the complex relations between Rome and Jerusalem, the dramatic conditions of the patriarchate during the war and the actions undertaken for the relief of Palestinian refugees via the CNEWA and the Pontifical Mission for Palestine (PMP), as well as the conflicts and attempts at unity between Latin and Eastern Catholics in the 1940 and 195 os.

29 Vincent Lemire, ed., Jérusalem: Histoire d'une ville-monde des origines à nos jours (Paris: Flammarion, 2016).

30 See Nina Valbousquet, "L'ouverture interrompue des archives de Pie XII: une enquête en suspens," Entre-Temps, May 11, 2020, and David I. Kertzer, "What the Vatican's Secret Archives Are About to Reveal," The Atlantic, March 2, 2020. 
The overlapping and cross-referencing of some fonds from the Pius archives with other ecclesiastical, diplomatic and private archives allows for a more complex and nuanced appraisal of the church's pastoral actions, its internal debates and the political relations with the Israeli state and the Jordanian kingdom.

However, this is also a history of missing fragments. The unsatisfactory preservation conditions and irregular access to the archives of the United Nations Relief and Works Agency for Palestine Refugees in the Near East (UNRWA), due to the organization's political and financial crises, reduces the availability of reliable data on Palestinian refugees and prevents a complete historical reconstruction of the diaspora of the Palestinian Catholics after 1948. ${ }^{31}$ Their closure is an urgent matter that needs to be addressed immediately. Moreover, the difficulty in accessing the Jordanian state archives remains a major problem for scholars, highlighting the peril of studying a country "from without", 32 only through foreign sources, mainly located in Israel, Europe and the United States. However, the consultation of Jordanian parish archives and the local press has partially mitigated this risk.

This documentary variety has made possible an attempt to reconstruct not only the institutional history of the Jerusalem Latin Church but also the evolution of political, social and religious behavior during and since the 1947-49 war, of the liturgy, of popular and ordinary forms of worship and piety, thus opening up a perspective capable of hybridizing religious, political and social histories as well as retracing the multiple trajectories taken by Catholic actors during and after 1948.

\subsection{Jerusalem's Connections and Global Entanglements: a Roadmap}

Diocesan monographs generally favor longue durée and structure with respect to articulation, to use the language of the Annales. In this case, however, the chosen periodization covers just a decade - a chronologically brief time span marked by crises and transformations, accelerations and bars to progress.

31 On UNRWA's historical archives in Amman and Gaza and the importance of Palestinian refugee archives, see Nur Masalha, "Decolonising Methodology, Reclaiming Memory: Palestinian Oral Histories and Memories of the Nakba," in An Oral History of the Palestinian Nakba, ed. Nahla Abdo and Nur Masalha (London: Zed, 2018); Peter Gatrell, The Making of the Modern Refugee (Oxford: Oxford University Press, 2013), 118-47, and Salim Tamari and Elia Zureik, eds., Reinterpreting the Historical Record: The Uses of Palestinian Refugee Archives for Social Science Research and Policy Analysis (Jerusalem: Institute of Jerusalem Studies, 2001).

32 Eugene L. Rogan, "Archival Resources and Research Institutions in Jordan," Middle East Studies Association Bulletin 23, no. 2 (1989): 169. 
Symbolically, however, it is a very long period: the $1947-49$ war represents the apex of a conflict that had dragged on from the end of the nineteenth century, one that remained unresolved in the decades that followed, to become exacerbated right after the transformations set in motion in 1948.

After unpacking the relations between the Latin Patriarchate of Jerusalem, the Zionist movement and the Middle Eastern Arab world from the nineteenth century to the Second World War, chapters 1 to 3 focus on the 1947-49 conflict, retracing and interpreting it using a host of sources, especially contemporary accounts offered by men - and some women - who were members of or had ties to the Jerusalem diocese, written in the course of events or in the immediate postwar phase. The international discussion on the partition of Palestine at the end of the Second World War, the role of the churches in the debate undertaken by United Nations organizations, the anxieties and fears of a possible establishment of a Jewish state and of a Muslim reaction to it are some of the themes addressed. The bloody battles of 1948, the refugee exodus, the closure of parishes in the territory that now forms part of the State of Israel, and the reorganization of the dioceses following the arrival of thousands of Catholic refugees in Transjordan provoked profound transformations in the life of the Latin community. In those months, the death in 1947 of Patriarch Luigi Barlassina, who had assumed the position in 1920, and the delay in selecting a successor on the part of the Holy See, in such a dramatic phase, sharpened the perception of isolation and radical upheaval which the war had produced in the minds of the clergy and faithful of the patriarchate. The nomination of the new patriarch, despite the rumors of a possible creation of a single diocese for Latin and Eastern Catholics, came at the end of 1949. The Franciscan Alberto Gori, custos of the Holy Land from 1937, found himself at the head of a diocese that was on its knees due to the conflict. The first emergency was that of providing aid for the refugees, for which the Holy See organized a specific agency, the PMP, in which the patriarchal diocese was an essential actor.

The first half of the 1950s, the focus of chapters 4 and 5, places the ecclesiastical institutions and their faithful in the foreground of the transformations sparked by the conflict of 1947-49. The church swung into action to contest laws by means of which the Israeli and Jordanian states, in the process of consolidating their own structures, intended to circumscribe and limit the activity of Christian organizations, especially aid and educational entities. The Latin diocese, and the congregations that operated within it, reacted to what they saw as an attack on the religious freedom of the Christian minority. In this context, the intervention of European diplomacy with traditional links to the Holy Land proved largely ineffective, putting an end to any possibility of restoring 
an indirect capitulatory regime and the beginning of a new phase marked primarily by the rise of nationalisms. ${ }^{33}$

In Israel, the debate over the importance of the Christian presence in the country became extremely tense, within a context rent by internal divisions among various Jewish components in the country. The specter of mass conversions from Judaism to Christianity, a scenario circulated by the Israeli press, drove the Israeli parliament - the Knesset - to elaborate a particularly harsh outline of bills regarding converts. In parallel, the theme of Jewish converts became the object of a lengthy negotiation between the Holy See and the Latin Patriarchate, leading to the birth of the Association of Saint James, a community that emerged from within the Latin diocese for converts and Christians of Jewish origin. The group of priests and laymen within the Association of Saint James inaugurated an experience of relations between the Jewish and Christian worlds with unprecedented and important consequences for the Latin Church of Jerusalem and the international panorama of relations between Jews and Catholics.

Chapters 6 to 8 place the history of the Jerusalem Latin diocese in a global context. The relationship between the Vatican and Jerusalem, especially regarding the troubled projects to unite the Latin and Eastern Catholic churches, but also the spiritual references and politicization in the area of devotion and cults, all contributed to the placing of the Latin Church of Jerusalem in a broader scenario. The rhetoric of a "crusade" for the Holy Places opened up new spaces for action in sectors of the US, Latin American and European Catholic world (especially in France, Italy and Belgium), which, during and after the 194749 war, were mobilized into campaigns of prayer and manifestations aimed at influencing the diplomacy of their respective countries to induce them to vote for the internationalization of Jerusalem, as wished by the Holy See. In

33 Ahdnäme was the term used by the Ottoman chancery to define all the agreements that the Sublime Porte stipulated to rule its relations, alliances, international trades, privileges (imtiy $\bar{a} z \bar{a} t$ ) with harbi countries as well as the condition of foreigners, the jurisdiction in matters of personal status of non-Muslim subjects within the empire. On September 8, 1914, Sultan Mehmet v proclaimed the abolition of "all the existent foreign privileges known as financial, economic, juridical and administrative capitulations". See Yusuf Hikmet Bayur, Türk Inkilabı Tarihi (Istanbul: Turk Tarik Kurumu, 1940), 162. After the First World War, the Treaty of Sèvres (1920) restored the capitulations, but the Treaty of Lausanne (1923) stipulated their definitive abolition. For a complete analysis, see Maurits H. van den Boogert, The Capitulations and the Ottoman Legal System: Qadis, Consuls and Beraths in the 18th Century (Leiden: Brill, 2005), and John Edward Wansbrough et al., "Imtiyāzāt [Capitulations]," in The Encyclopedia of Islam, ed. Hamilton Alexander Rosskeen Gibb (Leiden: Brill, 1986). 
the 1950s, the relaunching of the Marian cult with an anticommunist register assumed a great degree of importance, marked in the Jerusalem diocese by the construction of the Basilica of the Annunciation at Nazareth. The story of this tortuous project reveals the differences and distances in interpretations and meanings between the local church and the central authority within a politicized aspect of Marian devotion. All this sheds light on the fragmentation that existed between the Vatican and Jerusalem in the panorama of religious intentions and objectives.

From the geopolitical perspective, the bipolar conflict resulted in a redefinition of center and periphery. The year 1956 took on a paradigmatic importance: the Suez crisis placed the Middle East at the center of the global checkerboard. For the church, the events at Suez foregrounded in all clarity the instability of the political framework that resulted from the 1947-49 war, the very aspect in which it was laboriously searching for its own place and role. At the same time, a new phase was beginning. All of this was manifested more clearly in the actions of the Latin Patriarchate during the Second Vatican Council and, a few years later, in the upheaval following the war in June 1967.

Thus, this book weaves diocesan history with global history. Overall, in the decade from 1946 to 1956, the Jerusalem Latin diocese, as split between Israel, Jordan, Egypt and Cyprus, seems to have been a laboratory of different and sometimes divergent conceptions and tensions. Its multiformity, occasioned by the presence of Arab faithful and clergy, of European, American, Asian and African religious and, finally, a minority of converted Jews, stands out within an even more variegated panorama composed of the Christian confessions, the Muslim component - both Palestinian and Jordanian - and that of Israeli Jewish society, itself in turn reflecting further fragmentations (between Ashkenazi, Sephardi, Mizrahi and Ethiopian Jews, immigrants from the late Ottoman and Mandate period and those who arrived after 1948, orthodox and secular, to name but a few reductive and simplified categories). In the tangle of the epochal and periodizing historical events that followed the Second World War in the Middle East, the approach and considerations typical of Western Orientalism historically elaborated by Western clergy in relation to the Arab world underwent new changes and remodeling. In the same way, and concurrently with the upheavals of war, the anti-Western opposition of the Palestinian and Jordanian clergy also manifested itself at this time, especially in their call for an Arab patriarch after the death of Barlassina and in the 1950s. The antiJewish sentiments shared by the Western clergy and the Arabs now served as a precarious cohesive force between the two most important components of the Latin Church. However, here too something was moving: the tormented genesis within the patriarchate itself of a community - the Association of Saint 
James - animated by assumptions that largely dismantled the traditional attitude of suspicion and hostility toward the Jews present in the Catholic Church, reveals the necessity for a historical perspective capable of accommodating diverse histories and developments within the same, liminal, community.

These narratives, different and often conflicting - in counterpoint, so to say, and not in harmony ${ }^{34}$ - reveal the richness of an area of study, that of diocesan history, showing how it can be resumed and renovated.

Historical work is often perceived as an individual, solitary enterprise. On the contrary, sharing research experience, debating and receiving corrections and help have constantly marked the preparation of this book.

Paolo Pieraccini, with his abundant availability and tenacious interest in sources, supported me in identifying and exploiting unexplored archives. Daniele Menozzi, who supervised my doctoral thesis on which this book is based, taught me to be patient in approaching and analyzing documents and enriched this work with fragments of his expertise.

After defending my PhD at the Scuola Normale Superiore in Pisa, I had the chance to join the ERC Open Jerusalem project. Vincent Lemire, its director, gave me the privilege to participate in wide-ranging research, a collaborative adventure and a unique experience in historical and human training. In their daily work, the members of the Open Jerusalem core team - Stéphane Ancel, Yasemin Avcı, Louise Corvasier, Leyla Dakhli, Angelos Dalachanis, Abdul-Hameed al-Kayyali, Falestin Naili, Yann Potin and Katerina Stathi taught me how to overlap and cross-check archives and, above all, to recognize my limits and weaknesses and to transform them into opportunities for mutual collaboration, scientific advancement and personal growth.

Angelos Dalachanis and Vincent Lemire, who agreed to publish this book in the Open Jerusalem series, did not spare themselves in identifying errors,

34 Contrapuntal history aims to retrace diverse plot threads, following the itineraries of the diverse actors who compose a social reality animated by tensions, dialectics and contradictions, therefore creating a polyphonic narration that does not attempt to recompose irreconcilable elements into a false synthesis, or harmony as such. For this theorization and the connections between contrapuntal reading and liminality, the contribution by the Palestinian intellectual and theoretician of Orientalism Edward W. Said is seminal, especially in Culture and Imperialism (New York: Knopf, 1993), notably 18-19, 66-67 and 318. 
raising questions and offering suggestions. I am deeply grateful to the two anonymous reviewers for their precious corrections and illuminating remarks. Erika Mandarino, Katelyn Chin and Kayla Griffin, editors of the Open Jerusalem series at Brill, smoothly assisted me in all stages of the publication. Ela Harrison translated a large part of the manuscript with competence and interest. The copy editor of the volume, Damian Mac Con Uladh, offered invaluable expertise, dedication and attention to each detail.

The investigation at the basis of this book was made possible thanks to the hospitality of numerous research centers: in 2011 Olivier Tourny, then director of the Centre de recherche français in Jerusalem, welcomed me as a doctoral candidate, offering a most congenial working environment, which I would also enjoy in the following years in the Institut français du Proche-Orient in the Palestinian territories, the Ecole Normale Supérieure in Paris, the Analyse Comparée des Pouvoirs Department at Université Gustave-Eiffel in ParisEst Marne-la-Vallée, and the History Department at Fordham University, New York.

Marcella Simoni and Magda Teter, supervisors of my Marie SkłodowskaCurie Global Fellowship at Ca' Foscari of Venice and Fordham universities, nourished this book with their stimulating courses and meticulously argued writings.

Since our first meeting in Jerusalem, Arturo Marzano has provided thoughtful comments on my research, as well as his constant encouragement and precious friendship. Roberto Mazza proposed relevant corrections and insights, always replying enthusiastically to my requests.

This book or part of it benefited from the fundamental reflections, conversations, corrections, research experience and reading tips of Matteo Al Kalak, Elena Bacchin, Claire Beaugrand, Roberto Benedetti, Julien Blanc, Fr. Frans Bouwen, Michelle Campos, Matteo Caponi, Amnon Cohen, Raymond Cohen, Emmanuelle Giry, Jonathan Gribetz, Katharine Halls, Hagit Halperin, Hassan Hassan, Bernard Heyberger, Sarit Kattan Gribetz, Paolo Maggiolini, Claire Maligot, Elena Mazzini, Fr. Rafic Nahra, Charbel Nassif, Fr. David Neuhaus, Catherine Nicault, Jacob Norris, Inger Marie Okkenhaug, Maria Antonia Paiano, Giamberto Pegoraro, Emeline Rotolo, Mariuccia Salvati, Karène Sanchez Summerer, Guri Schwarz, Salim Tamari, Jean-Marc Ticchi, Dominique Vidal and Paolo Zanini. Naturally, I remain responsible for any remaining errors.

The archival directors and personnel staff of several archives across Europe, the Middle East and the United States assisted me. Among them, I acknowledge a particular debt of gratitude to Msgr. William Shomali, who granted me the access to the Latin Patriarchate archives in Jerusalem; to Fr. Narcyz Klimas and Fr. Sergey Loktionov, for their readiness to provide 
access to the Franciscan Custody archives; to Fr. Jean-Daniel Gullung for making available the Jean-Roger Héné papers at the Assumptionist archives; to Br. Elio Passeto, who granted me access to the Fathers of Sion archives; to Fr. Jean-Michel de Tarragon for allowing me consult and use the enormous richness of the École biblique et archéologique française photographic collections; to Gianpaolo Rigotti and Maria Carosio, who made every effort to facilitate my requests to visit the archives of the Congregation for the Oriental Churches in Rome; to Stefania Ruggeri for her help at the archives of the Italian Ministry of Foreign Affairs; to Fr. Lawrence Frizzell and Alan B. Delozier for their assistance in consulting the John M. Oesterreicher collection at the Seton Hall University Archives in New Jersey.

As preparation for this book was in its final stages, Yohanan Elihai passed away aged 94. In 2011 he generously showed me the documentation on the Association of Saint James that he had collected since the 195os. The memories he so gently shared with me from that point, for which I am eternally grateful to him, inspired me to embark on the research for this book.

Throughout this journey from Jerusalem to the archives and back, I have always been accompanied by Riccardo, whose firm presence and brilliant intuition to locate hidden sources anticipated many steps of my work and life. Giacomo and Filippo make this joint journey into the future such a bright one. 